\title{
3 Research Square

\section{Negative effects of iodine-based contrast agent on renal function in patients with moderate reduced renal function hospitalized for Covid-19}

Chen Tamm

Karolinska University hospital, Karolinska Institutet

Ann Mari Svensson

Karolinska University hospital, Karolinska Institutet

Mats O. Beckman

Karolinska Institutet

Fredrik Strand

Karolinska University hospital, Karolinska Institutet

Magnus Sköld

Karolinska Institutet

Sven Nyrén

Karolinska University hospital, Karolinska Institutet

Anna Kistner ( $\nabla$ anna.kistner@ki.se )

Karolinska University Hospital, Karolinska Institutet

\section{Research Article}

Keywords: lodinated contrast, Computed tomography, Covid-19, P-creatinine, contrast-induced acute renal failure

Posted Date: March 30th, 2021

DOI: https://doi.org/10.21203/rs.3.rs-342119/v1

License: (c) (1) This work is licensed under a Creative Commons Attribution 4.0 International License. Read Full License 


\section{Abstract}

Background Kidney disease and renal failure are associated with hospital deaths in patients with Covid19. We aimed to test if contrast enhancement (CE) affects short-term renal function in hospitalized Covid19 patients.

Methods Plasma creatinine (P-creatinine) was measured on the day of computed tomography (CT) and $24 \mathrm{~h}, 48 \mathrm{~h}$, and $4-10$ days after CT. CE $(n=142)$ and non-CE $(n=24)$ groups were subdivided, based on estimated glomerular filtration rates (eGFR), $>60$ and $\geq 30-60 \mathrm{ml} / \mathrm{min} / 1.73 \mathrm{~m}^{2}$. Contrast-induced acute renal failure (Cl-AKI) was defined as $\geq 27 \mu \mathrm{mol} / \mathrm{L}$ increase or a $>50 \%$ rise in P-creatinine from $\mathrm{CT}$ or initiation of renal replacement therapy (RRT) during follow-up. Patients with RRT were studied separately. We evaluated factors associated with $a>50 \%$ rise in P-creatinine.

Results Median P-creatinine at 24-48 $\mathrm{h}$ and days $4-10$ post-CT in patients with eGFR $>60$ and eGFR $\geq$ 30-60 in CE and non-CE groups did not differ from basal values. Cl-AKI was observed at $48 \mathrm{~h}$ and at 410 days post-CE in $24 \%$ and $36 \%(n=5 / 14)$ of patients with eGFR $\geq 30-60$. Corresponding figures in the eGFR $>60$ CE CT group were $5 \%$, $\left(p<0.037\right.$ and $p<0.001$, Pearson $x^{2}$ test respectively). In the former group, four of the five patients died within 30 days. Odds ratio analysis showed that $\mathrm{Cl}-\mathrm{AKI}$ was associated with an eGFR $\leq 60$ at CE and 30-day mortality both at $48 \mathrm{~h}$ and $4-10$ days.

Conclusion Patients with Covid-19 and eGFR $\geq 30-60$ had a high frequency of CK-AKI at $48 \mathrm{~h}$ and at 410 days after $C E$, which was associated with increased 30-day mortality. For patients with eGFR $\geq 30-60$, we recommend strict indications are practiced for CE CT. CE had a modest effect in patients with eGFR > 60.

\section{Introduction}

lodine-based contrast agents for intravascular use may have a negative effect on kidney function, particularly in previously compromised kidneys (1). Contrast-induced acute kidney injury (Cl-AKI) has been defined as an increase in plasma $(P)$-creatinine measured 2-3 days after computed tomography (CT) (2). A previous definition used a P-creatinine increase of $44 \mu \mathrm{mol} / \mathrm{L}$ or above as diagnostic (3). A recent guideline recommends a lower limit (2). Patient related factors are known to affect the risk; most importantly kidney function, which is usually expressed as, estimated glomerular filtration rate (eGFR). A value $<60 \mathrm{ml} / \mathrm{min} / 1,73 \mathrm{~m}^{2}$ has been used to define a somewhat higher risk. eGFR $<30 \mathrm{ml} / \mathrm{min} \times 1.73 \mathrm{~m}^{2}$ indicates severe renal failure and is considered a risk factor for $\mathrm{Cl}-\mathrm{AKI}(1,2)$. The incidence of $\mathrm{Cl}$-AKI was shown to range from 0 to $24 \%$, with the highest risk in diabetic nephropathy (4). Other background factors of importance are kidney surgery, proteinuria and hypertension (2). It is also well known that severity of present disease increases the risk substantially (5).

Thromboembolic diseases, including pulmonary embolism (PE), are seen with a high frequency in Covid$19(6,7)$. The primary method for confirming pulmonary embolism is CT angiography (8). Suspected PE was the dominating indication for CT angiography in our study. Cl-AKI was defined as an increase in P- 
creatinine $\geq 27 \mu \mathrm{mol} / \mathrm{L}$ or $>50 \%$ rise in P-creatinine above the value on the day of CT (2). Kidney disease and renal failure were associated with hospital death in Covid-19 (4). This raised the question of whether patients with Covid-19 might be more susceptible to the harmful effects of iodinated contrast material (9). This possibility could influence risk assessments whether a CT angiogram is performed in Covid-19. We hypothesized that, in patients with Covid-19, the administration of contrast enhancement (CE) would increase P-creatinine and reduce eGFR to a greater extent than a non-CE approach in patients with a moderate renal impairment and eGFR $\leq 60 \mathrm{ml} / \mathrm{min} \times 1.73 \mathrm{~m}^{2}$.

\section{Methods}

This retrospective study was approved by the Ethical Review authority, (Dnr 2020-01882), and informed consent was waived. From March 19 to May 31, 2020, we included all patients with a PCR test positive for SARS-CoV-2 that were referred to thoracic or abdominal CT at our hospital.

\section{Measurements}

We collected P-creatinine measured on the day of before CT and $24 \mathrm{~h}, 48 \mathrm{~h}$, and 4-10 days after CT, when available. P-creatinine (anticoagulated with Li-heparin) was analyzed with an enzymatic photometric method (Cobas ${ }^{\circledR}$, Roche Diagnostics, $\mathrm{GmbH}$, Mannheim, Germany). The reference values were $<100$ $\mu \mathrm{mol} / \mathrm{L}$ for men and $<90 \mu \mathrm{mol} / \mathrm{L}$ for women. Pre-Covid-19 levels of P-creatinine were retrieved from patient records up to two years before the current hospitalization.

eGFR was calculated according to the chronic kidney disease epidemiology collaboration (CKD-EPI) formula (2). An eGFR $\geq 90 \mathrm{ml} / \mathrm{min} \times 1.73 \mathrm{~m}^{2}$ was taken as normal, values below eGFR 60 indicated moderate reduced renal function and values below 30 indicated severe renal failure (2). Cl-AKI was defined as an increase in P-creatinine $\geq 27 \mu \mathrm{mol} / \mathrm{L}$ or $>50 \%$ rise in P-creatinine above the value on the day of CT (2).

CT was performed with a 256-slice multi-detector Revolution CT (GE Healthcare). The CE (Omnipaque $350 \mathrm{mg} / \mathrm{ml}$ ) was applied at a flow rate of $5 \mathrm{ml} / \mathrm{s}$.

We collected data on patient age, sex, weight, height, body mass index (BMI), anti-thrombotic treatment, co-morbidities, C-reactive protein (CRP; reference value $<5.0 \mathrm{mg} / \mathrm{l}$ ) measured at the time of the CT scan, the contrast dose, intensive care unit (ICU) stay and 30-day mortality. CRP was determined with an immuno-turbidimetric analysis (Cobas ${ }^{\circledR}$, Roche Diagnostics, GmbH, Mannheim, Germany).

\section{Study groups}

The patient selection process is shown in Figure 1.

During the study period, 166 patients met the inclusion criteria. Among these, seven patients were included twice, because they underwent CT scans with and without CE. No patient underwent a repeated CE CT scan or a repeated non-CE CT scan. 
Patients were divided into subgroups depending on renal function. The subgroups were defined as an eGFR $>60 \mathrm{ml} / \mathrm{min} \times 1.73 \mathrm{~m}^{2}$ (eGFR>60) or an eGFR $\leq 60 \mathrm{ml} / \mathrm{min} \times 1.73 \mathrm{~m}^{2}$ (eGFR $\left.\leq 60\right)$. Patients on RRT at CT $(n=20)$ were analyzed separately.

\section{Statistics}

Anthropometric and laboratory data are presented as median and interquartile range (IQR, Table 1). Student t-test, analysis of variance (ANOVA), and Pearson's $x^{2}$-test were used for comparisons of categorical variables. Logistic regression analyses were used to calculate the odds ratio (OR) and $95 \%$ confidence interval $(\mathrm{Cl})$ (Table 2). We performed odds ratio analyses to investigate associations between P-creatinine $48 \mathrm{~h}$ after $\mathrm{CT}$ and P-creatinine 4-10 days after CT. A P-value $<0.05$ was considered significant. All statistical analyses were performed with Statistical Stat Soft, version 10.

\section{Results}

\section{Patients with eGFR $>60 \mathrm{ml} / \mathrm{min} \times 1.73 \mathrm{~m}^{2}$ without existing RRT examined with CE}

The median P-creatinine levels at CT were 61 and $65 \mu \mathrm{mol} / \mathrm{L}$ in 110 patients with CE CT and in 8 patients with non-CE CT, respectively. The median P-creatinine values changed minimally at follow up (Table 1a). However in the CE CT group, five of 97 patients studied at $48 \mathrm{~h}$ and four of 78 patients studied at 4-10 days showed an increase in P-creatinine above definition for CI-AKI (Table 1a, Fig 2a).

At $48 \mathrm{~h}$, the P-creatinine in three out of four of these patients was already above definition for Cl-AKI. Two of these patients had RRT on day 7. In three of the four patients with a $>50 \%$ increase in P-creatinine after 4-10 days, the median pre-Covid-19 P-creatinine level was 83 (IQR: 65-104) $\mu \mathrm{mol} / \mathrm{l}$.

Six patients died before the 4-10-day follow-up. Of these patients, one had a $200 \%$ rise in P-creatinine at $48 \mathrm{~h}$, not seen in the other five patients.

\section{Patients with eGFR $\geq 30-60 \mathrm{ml} / \mathrm{min} \times 1.73 \mathrm{~m}^{2}$ without existing RRT examined with CE}

In the CT CE group the median P-creatinine was $130 \mu \mathrm{mol} / \mathrm{I}(\mathrm{n}=17$ patients; Table 1a). This value remained unchanged at 24-48 $\mathrm{h}$, and at 4-10 days after CE exposure for the whole group (Table 1a). However, at $48 \mathrm{~h}$, the incidence of a P-creatinine rise above definition for Cl-AKI was observed in $24 \%$ vs $5 \%$ in the CE CT eGFR>60 group ( $p=0.037$, Table 1a). Five out of 14 patients that remained at follow-up days 4-10 showed a $>50 \%$ P-creatinine increase, including initiation of RRT in two cases (Fig 2a, Table 1a). This incidence was higher than the figures observed in the CE CT eGFR> 60 group ( $36 \%$ vs $5 \%$, $p<0.001$, Table 1a) and also compared with the eGFR<60 group not receiving CE (36\% vs $0 \%, p=0.043, x^{2}$ test). These five patients had initial P-creatinine values of 121, 124, 129, 130, and $182 \mu \mathrm{mol} / \mathrm{L}$ (Fig 2a), and median pre-Covid P-creatinine of 97 (IQR: 82-106) $\mu \mathrm{mol} / \mathrm{L}$. Three of these patients had a pre-Covid eGFR $<60 \mathrm{ml} / \mathrm{min} \times 1.73 \mathrm{~m}^{2}$. These five patients did not seem to differ in pre-Covid P-creatinine compared with other patients in the CE CT $\geq 30-60$ group (Table $1 \mathrm{~b}$ ). Four of these five patients died within 30 days 
of the CE CT (Fig 2b) and in total, 30-day mortality was $53 \%$ in the whole group. Two of these patients died before follow up at 4-10 days. Of the two patients that died before follow-up, one showed a rise in Pcreatinine above definition for $\mathrm{Cl}-\mathrm{AKI}$ at $24 \mathrm{~h}$.

A higher pre-Covid-19 prevalence of renal disease and hypertension was seen in the eGFR $\geq 30-60 \mathrm{CE}$ CT group compared with the eGFR>60 CE CT group (Table 1a). None of CE CT patients with eGFR $\leq 60$ had an eGFR<30 $\mathrm{ml} / \mathrm{min} \times 1.73 \mathrm{~m}^{2}$.

\section{Patients with eGFR $\leq 60 \mathrm{ml} / \mathrm{min} \times 1.73 \mathrm{~m}^{2}$ without existing RRT examined without CE}

In the non-CE CT group, among the 11 patients with eGFR $\leq 60$, the initial median P-creatinine level was $163 \mu \mathrm{mol} / \mathrm{l}$, which was significantly higher than the levels observed in the other groups. In this group, the median P-creatinine level fell progressively during follow-up (Table 1a). At 4-10 days after CT, none of nine patients showed a $50 \%$ increase in P-creatinine. 30-day mortality was $18 \%$ compared with $53 \%$ in the eGFR $\geq 30-60$ CE CT group ( $p=0.07, x^{2}$ - test). Two of non-CE CT patients with eGFR $\leq 60$ had an eGFR<30 $\mathrm{ml} / \mathrm{min} \times 1.73 \mathrm{~m}^{2}$.

In the non-CE CT group, no patient received RRT after CT during the study period.I

\section{Patients with existing RRT examined with CE}

This group $(n=15)$ received higher doses of contrast agent than the doses given to patients that were not taking RRT (median doses: $110 \mathrm{ml}, 95 \% \mathrm{Cl}$ : $60-129$ vs. $60 \mathrm{ml}, 95 \% \mathrm{Cl}: 60-70 ; \mathrm{p}<0.001$ ). The median Pcreatinine levels in this group declined from 161 at baseline to $127 \mu \mathrm{mol} / \mathrm{L}$ at $48 \mathrm{~h}$; then it rose to 188 $\mu \mathrm{mol} / \mathrm{L}$ at 4-10 days after CE exposure (not significantly different from baseline; Table 1C).

After 4-10 days, we observed a $>50 \%$ increase in P-creatinine in five out of remaining 14 patients in the RRT with CE CT group and only one out of 21 patients in the non-RRT non-CE CT group (36\% vs. 5\%; $p=0.017$; Table 1b). Among the 24 patients that received a CT without CE during the study period, five were taking RRT at the time of the CT (5 patients included in Table 1c).

\section{Odds ratio analysis}

Odds ratio analysis indicated that a $>50 \%$ rise in P-creatinine after $48 \mathrm{~h}$ and after 4-10 days was associated with eGFR $\leq 60$ and CE at CT, with 30-day mortality and with RRT at CT (Table 2).

\section{Discussion}

We hypothesized that the administration of iodine-based CE to patients with Covid- 19 would affect Pcreatinine and renal function. In the present study, in all subgroups of renal function, small changes were seen in median values 24-48 hours after CE exposure. However, our findings indicated that in $24-36 \%$ of patients with moderate renal failure and an eGFR of $30-60 \mathrm{ml} / \mathrm{min} \times 1.73 \mathrm{~m}^{2}$ at the time of the CT, CE had a negative effect on renal function. These figures were significantly higher than the $5 \%$ observed in 
patients with eGFR >60 and CE. Not surprisingly mortality was higher in CE patients with eGFR of 30-60 compared with those with eGFR above 60 (53\% vs 11\%). More patients with eGFR between 30-60 given CE developed CK-AKI compared to those not receiving CE (24-36\% vs 0\%). Patients in the non-CE CT group with eGFR $\leq 60$ had high CRP and significantly higher median P-creatinine at CT scan compared with the eGFR $\geq 30-60$ CE CT group. Despite this, 30-day mortality showed a tendency to be lower in the non-CE CT group. This indicates that Cl-AKI identified a vulnerable group of Covid-19 patients.

The findings related to RRT are difficult to interpret without detailed knowledge of the RRT-intensity or diuresis. Not surprisingly, renal failure after CE CT was associated with an ICU stay and with 30-day mortality, but only slightly with age.

Barrios-Lopez et al reported, before the Covid-19 era, that the incidence of CK-AKI was only $1 \%$ in patients with chronic renal disease and eGFR $30-60 \mathrm{ml} / \mathrm{min} \times 1.73 \mathrm{~m}^{2}(10)$. The peak P-creatinine level is typically observed within 2 to 5 days after a contrast medium injection (10).

The risk factors associated with acute kidney injury after an iodinated contrast injection include advanced age, hypovolemia and dehydration, type 2 diabetes, and previously impaired kidney function (11). Chronic kidney disease was proposed to be the strongest risk factor associated with developing a contrast-associated acute kidney injury (12). Moreover, critically ill patients are at increased risk of CKAKI. In 2011, Hoste et al reported that one out of six patients in the ICU developed CK-AKI (5). However, in a recent large meta-analysis with a control group, acute kidney injury was not associated with the administration of iodinated contrast material (13).

Deep vein thrombosis was found in $40 \%$ of autopsies in 80 cases with Covid-19 in Germany (14). Covid19 was associated with an increased risk of thrombosis in both the micro- and macrovasculature (15). Acute kidney injury is a complication associated with severe Covid-19 infections (16). Microthrombosis might be involved in the decline of kidney function in patients with Covid-19. Furthermore, renal tubule cells may be targeted in Covid-19, because these cells express receptors for Sars-CoV-2 (17). In experimental studies, contrast agents reduced renal blood flow and induced oxygen free radicals, a scenario that leads to apoptosis of renal tubular cells (18) and reduced GFR.

Our patients with eGFR of 30-60 at the time of CE CT had higher CRP levels and a higher incidence of chronic renal disease before CT, compared to patients with eGFR>60 at the time of CE CT. Severely ill patients with Covid-19 that have moderate renal dysfunction might be more prone to the effects of iodinated contrast agents, due to the combination of the previous kidney disease and the SARS CoV-2 effect on tubular cells. Severe renal failure is a contra-indication for contrast agent injections; this is the main reason for the high P-creatinine levels found in the non-CE CT group.

Our study had some limitations. First, we evaluated relatively small numbers of patients in most of our study groups. Second, we lacked follow-up P-creatinine values at 4-10 days in $28 \%$ of patients in the eGFR>60 CE CT group. The reasons for this loss included death before follow-up $(n=6)$, missing follow-up P-creatinine levels, and, hospital discharge. 
Four out of 127 patients in the CE CT group initiated RRT during the study period. Among the patients that were taking RRT at the time of the CT scan, normal contrast doses did not cause obvious negative effects, compared to other patients with eGFR $\leq 60 \mathrm{ml} / \mathrm{min} \times 1.73 \mathrm{~m}^{2}$. However RRT at CE CT was associated with a $>50 \%$ rise in P-creatinine at 4-10 days and caution before CE CT for this group of patients seems appropriate.

To minimize the risks for CK-AKI we recommend that strict indications are practiced for CE CT in patients with an eGFR $\geq 30-60 \mathrm{ml} / \mathrm{min} \times 1.73 \mathrm{~m}^{2}$. Perhaps iodinated contrast agent should not be administrated to Covid-19 patients with eGFR below 60 protected by full-dose thromboembolic treatment. If considered necessary CE CTs should be performed with a low kV setting and the lowest possible dose of a low- or iso-osmolality contrast agent (19). In addition, an infusion of isotonic saline, started hours before exposure to contrast agents, has been proposed for protection against CK-AKI (20).

In conclusion, we demonstrated that hospitalized Covid-19 patients with moderate renal impairment and an eGFR of $30-60 \mathrm{ml} / \mathrm{min} \times 1.73 \mathrm{~m}^{2}$, showed an increased risk of worsened renal impairment after an iodine-based contrast injection. We observed $a>50 \%$ rise in P-creatinine or RRT initiation at 4-10 days after CE CT in $36 \%$ of patients with eGFR between $30-60$, compared to $5 \%$ of patients with eGFR above 60. This report could aid in risk assessments before ordering a CE CT in patients with Covid-19. Larger studies are needed to confirm our observations.

\section{Declarations}

Ethics approval: The authors hereby confirm that all methods were carried out in accordance with relevant guidelines and regulations. The Swedish Ethical Review Authority, Uppsala, Sweden, approved the waiver for informed consent for this retrospective study, application number 2020-01882.

Consent for publication: Not applicable

Availability of data and material: figshare.com

Competing interests: The authors declare no conflicts related to the submitted work

Funding: This study was supported by the Karolinska Institutet, Karolinska University Hospital, from KTH the Royal Institute of Technology, Stockholm, Sweden, and by a donation from Einar Mattsson.

Authors contribution: $\mathrm{AK}, \mathrm{MB}$, and $\mathrm{SN}$ were involved in the concept and design of the study. AK and $\mathrm{CT}$ performed the analysis of the data. AK, CT, AMS, MB, FS, MS och SN all contributed in the interpretation of the data. The first draft was written by AK and all co-authors were engaged in revising the final version of the manuscript. All co-auhors also did a final approval of the version to be published.

Consent to participate: Not applicable 
Availability of data and material: The datasets generated during and/or analysed during the current study are available from the corresponding author on reasonable request

\section{References}

1. Ronco C, Stacul F, McCullough PA (2013) Subclinical acute kidney injury (AKI) due to iodine-based contrast media. Eur Radiol 23:319-323. DOI: 10.1007/s00330-012-2607-y

2. van der Molen AJ, Reimer P, Dekkers IA, Bongartz G, Bellin MF, Bertolotto M, Clement O, Heinz-Peer G, Stacul F, Webb JAW, Thomsen HS 2018 Post-contrast acute kidney injury - Part 1: Definition, clinical features, incidence, role of contrast medium and risk factors : Recommendations for updated ESUR Contrast Medium Safety Committee guidelines. Eur Radiol 28:2845-2855.DOI: 10.1007/s00330-0175247-4.

3. Thomsen HS (2003) Guidelines for contrast media from the European Society of Urogenital Radiology. AJR Am J Roentgenol 181:1463-1471. DOI:10.2214/ajr.181.6.1811463

4. Hossain MA, Costanzo E, Cosentino J, Patel C, Qaisar H, Singh V, Khan T, Cheng JS, Asif A, Vachharajani TJ (2018) Contrast-induced nephropathy: Pathophysiology, risk factors, and prevention. Saudi J Kidney Dis Transpl 29:1-9. DOI:10.4103/1319-2442.225199

5. Hoste EA, Doom S, De Waele J, Delrue LJ, Defreyne L, Benoit DD, Decruyenaere J (2011) Epidemiology of contrast-associated acute kidney injury in ICU patients: a retrospective cohort analysis. Intensive Care Med 37:1921-1931. DOI:10.1007/s00134-011-2389-8

6. Helms J, Tacquard C, Severac F, Leonard-Lorant I, Ohana M, Delabranche X, Merdji H, Clere-JehI R, Schenck M, Fagot Gandet F, Fafi-Kremer S, Castelain V, Schneider F, Grunebaum L, Angles-Cano E, Sattler L, Mertes PM, Meziani F, Group CT (2020) High risk of thrombosis in patients with severe SARS-CoV-2 infection: a multicenter prospective cohort study. Intensive Care Med 46:1089-1098. DOI: 10.1007/s00134-020-06062-x.

7. Wichmann D, Sperhake JP, Lutgehetmann M, Steurer S, Edler C, Heinemann A, Heinrich F, Mushumba H, Kniep I, Schroder AS, Burdelski C, de Heer G, Nierhaus A, Frings D, Pfefferle S, Becker H, BrederekeWiedling H, de Weerth A, Paschen HR, Sheikhzadeh-Eggers S, Stang A, Schmiedel S, Bokemeyer C, Addo MM, Aepfelbacher M, Puschel K, Kluge S (2020) Autopsy Findings and Venous Thromboembolism in Patients With COVID-19. Ann Intern Med. 18;173(4):268-277. DOI: 10.7326/M20-2003.

8. Righini M, Robert-Ebadi H (2018) Diagnosis of acute Pulmonary Embolism. Hamostaseologie 38:1121. DOI:10.5482/HAMO-17-07-0023

9. Kooiman J, Pasha SM, Zondag W, Sijpkens YW, van der Molen AJ, Huisman MV, Dekkers OM (2012) Meta-analysis: serum creatinine changes following contrast enhanced CT imaging. Eur J Radiol 81:2554-2561. DOI:10.1016/j.ejrad.2011.11.020

10. Barrios Lopez A, Garcia Martinez F, Rodriguez JI, Montero-San-Martin B, Gomez Rioja R, Diez J, Martin-Hervas C (2020) Incidence of contrast-induced nephropathy after a computed tomography 
scan. Radiologia. May 18;S0033-8338(20)30038-2. DOI: 10.1016/j.rx.2020.02.002.Online ahead of print.

11. Lautin EM, Freeman NJ, Schoenfeld AH, Bakal CW, Haramati N, Friedman AC, Lautin JL, Braha S, Kadish EG, Sprayregen S, et al. (1991) Radiocontrast-associated renal dysfunction: incidence and risk factors. AJR Am J Roentgenol 157:49-58. DOI:10.2214/ajr.157.1.2048539

12. McCullough PA, Adam A, Becker CR, Davidson C, Lameire N, Stacul F, Tumlin J, Panel CINCW (2006) Risk prediction of contrast-induced nephropathy. Am J Cardiol 98:27K-36K.

DOI: 10.1016/j.amjcard.2006.01.022

13. Ehrmann S, Quartin A, Hobbs BP, Robert-Edan V, Cely C, Bell C, Lyons G, Pham T, Schein R, Geng Y, Lakhal K, Ng CS (2017) Contrast-associated acute kidney injury in the critically ill: systematic review and Bayesian meta-analysis. Intensive Care Med 43:785-794. DOI:10.1007/s00134-017-4700-9

14. Edler C, Schroder AS, Aepfelbacher M, Fitzek A, Heinemann A, Heinrich F, Klein A, Langenwalder F, Lutgehetmann M, Meissner K, Puschel K, Schadler J, Steurer S, Mushumba H, Sperhake JP (2020) Dying with SARS-CoV-2 infection-an autopsy study of the first consecutive 80 cases in Hamburg, Germany. Int J Legal Med 134:1275-1284. DOI: 10.1007/s00414-020-02317-w

15. Kamel MH, Yin W, Zavaro C, Francis JM, Chitalia VC (2020) Hyperthrombotic Milieu in COVID-19 Patients. Cells 9(11):2392. DOI: 10.3390/cells9112392

16. Nadim MK, Forni LG, Mehta RL, Connor MJ, Jr., Liu KD, Ostermann M, Rimmele T, Zarbock A, Bell S, Bihorac A, Cantaluppi V, Hoste E, Husain-Syed F, Germain MJ, Goldstein SL, Gupta S, Joannidis M, Kashani K, Koyner JL, Legrand M, Lumlertgul N, Mohan S, Pannu N, Peng Z, Perez-Fernandez XL, Pickkers P, Prowle J, Reis T, Srisawat N, Tolwani A, Vijayan A, Villa G, Yang L, Ronco C, Kellum JA (2020) COVID-19-associated acute kidney injury: consensus report of the 25th Acute Disease Quality Initiative (ADQI) Workgroup. Nat Rev Nephrol 16:747-764. DOI: 10.1038/s41581-020-00356-5

17. Xia S, Wu M, Chen S, Zhang T, Ye L, Liu J, Li H (2020) Long Term Culture of Human Kidney Proximal Tubule Epithelial Cells Maintains Lineage Functions and Serves as an Ex vivo Model for Coronavirus Associated Kidney Injury. Virol Sin 35:311-320 DOI:10.1007/s12250-020-00253-y

18. Bakris GL, Lass N, Gaber AO, Jones JD, Burnett JC, Jr. (1990) Radiocontrast medium-induced declines in renal function: a role for oxygen free radicals. Am J Physiol 258:F115-120.

DOI:10.1152/ajprenal.1990.258.1.F115

19. Mehran R, Dangas GD, Weisbord SD (2019) Contrast-Associated Acute Kidney Injury. N Engl J Med 380:2146-2155. DOI:10.1056/NEJMra1805256

20. Fahling M, Seeliger E, Patzak A, Persson PB (2017) Understanding and preventing contrast-induced acute kidney injury. Nat Rev Nephrol 13:169-180. DOI:10.1038/nrneph.2016.196

\section{Tables}

Table 1. Demographics, laboratory data, and outcome in patients with Covid-19, grouped by eGFR $>60$ or $\leq 60$ $\mathrm{ml} / \mathrm{min} \times 1.73 \mathrm{~m}^{2}$ and CT with or without $\mathrm{CE}$ 


\begin{tabular}{|c|c|c|c|c|c|}
\hline (a) Patients without RRT at CT & $\begin{array}{c}1 . \\
\text { eGFR } \geq 30- \\
60 \mathrm{CE} \\
(\mathrm{n}=17) \\
\end{array}$ & $\begin{array}{c}\text { 2. eGFR>60 } \\
\text { CE } \\
(n=110)\end{array}$ & $\begin{array}{l}3 . \\
\text { eGFR } \leq 60 \\
\text { non- } \mathrm{CE} \\
(\mathrm{n}=11)\end{array}$ & $\begin{array}{l}4 . \\
\text { eGFR }>60 \\
\text { non-CE } \\
(n=8)\end{array}$ & p-value* \\
\hline \multicolumn{6}{|l|}{ DEMOGRAPHICS } \\
\hline Men/women (n) & $14 / 3$ & $77 / 33$ & $7 / 4$ & $6 / 2$ & 0.65 \\
\hline Age (years) & $65(61-76)$ & $58(49-64)$ & \multirow{3}{*}{$\begin{array}{c}59(51- \\
68) \\
74(61- \\
87) \\
25(21- \\
29)\end{array}$} & \multirow{3}{*}{$\begin{array}{c}64(50- \\
70) \\
79(64- \\
90) \\
25(21- \\
27)\end{array}$} & 0.029 \\
\hline Weight (kg) & $75(72-87)$ & $80(72-93)$ & & & 0.53 \\
\hline BMI $\left(\mathrm{kg} / \mathrm{m}^{2}\right)$ & $25(23-30)$ & $28(24-31)$ & & & 0.19 \\
\hline \multicolumn{6}{|l|}{ Thromboembolic treatment } \\
\hline before CT exam (\%) $(\mathrm{n}=$ no/yes), $\mathrm{n}=144$ & $\begin{array}{c}76 \\
(\mathrm{n}=4 / \mathrm{n}=13)\end{array}$ & $\begin{array}{c}76(\mathrm{n}=26 / \\
\mathrm{n}=84)\end{array}$ & $\begin{array}{c}89 \\
(n=1 / n=8)\end{array}$ & $\begin{array}{c}88 \\
(n=1 / n=7)\end{array}$ & 0.75 \\
\hline \multicolumn{6}{|l|}{ CO-MORBIDITIES } \\
\hline $\begin{array}{c}\text { Renal disease } \\
(\%)(n=\text { no/yes }), n=144\end{array}$ & $25(4 / 12)$ & $0(0 / 109)$ & $55(6 / 5)$ & $13(1 / 7)$ & $<0.001$ \\
\hline $\begin{array}{l}\text { Hypertension } \\
\text { (\%) }(n=\text { no/yes }), n=141\end{array}$ & $60(9 / 6)$ & $36(38 / 68)$ & $64(7 / 4)$ & $13(1 / 7)$ & 0.037 \\
\hline 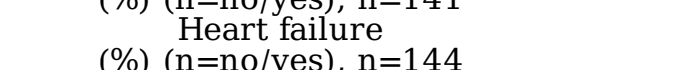 & $13(2 / 14)$ & $5(5 / 104)$ & $18(2 / 9)$ & $13(1 / 7)$ & 0.24 \\
\hline $\begin{array}{l}\text { Type } 2 \text { diabetes } \\
(\%) \text { (n=no/yes), } n=143 \\
\text { LABORATORY DATA }\end{array}$ & $24(4 / 12)$ & $20(22 / 86)$ & $18(2 / 9)$ & $25(2 / 6)$ & 0.96 \\
\hline P-creatinine at CT, $\mathrm{n}=146$ & $\begin{array}{c}130(121- \\
153)\end{array}$ & $61(48-76)$ & $\begin{array}{l}163(132- \\
201)\end{array}$ & $\begin{array}{l}65(45- \\
80)\end{array}$ & $\begin{array}{l}1 \text { vs } 3 \\
<0.001 / 2 \\
\text { vs } 40.85\end{array}$ \\
\hline reatinine $24 \mathrm{~h}$ after CT exam, $\mathrm{n}=127$ & $\begin{array}{l}130(118- \\
186)\end{array}$ & $61(49-74)$ & $\begin{array}{l}136(105- \\
151)\end{array}$ & $\begin{array}{l}63(43- \\
89)\end{array}$ & $\begin{array}{l}1 \text { vs } 3 \\
0.97 / 2 \text { vs } \\
40.97\end{array}$ \\
\hline reatinine $48 \mathrm{~h}$ after CT exam, $\mathrm{n}=128$ & $\begin{array}{l}130(111- \\
192)\end{array}$ & $62(50-73)$ & $\begin{array}{l}123(112- \\
159)\end{array}$ & $\begin{array}{l}69(54- \\
74)\end{array}$ & $\begin{array}{l}1 \text { vs } 3 \\
0.46 / 2 \text { vs } \\
4 \text { ns } 0.95\end{array}$ \\
\hline atinine $4-10$ days after $\mathrm{CT}$ exam, $\mathrm{n}=110$ & $\begin{array}{c}129(77- \\
197) \\
(\mathrm{n}=14)\end{array}$ & $\begin{array}{l}62(48-75) \\
(n=78)\end{array}$ & $\begin{array}{c}85(70- \\
124) \\
(\mathrm{n}=9)\end{array}$ & $\begin{array}{l}64(53- \\
79)(n=9)\end{array}$ & $\begin{array}{l}1 \mathrm{vs} 3 \\
0.09 / 2 \mathrm{Vs} \\
40.59\end{array}$ \\
\hline $\begin{array}{l}\text { nine rise }>26.5 \mu \mathrm{mol} / \mathrm{L} \text { or }>50 \% 48 \mathrm{~h} \text { after } \\
\text { CT exam }(\%)(\mathrm{n}=\text { yes } / \mathrm{n}=\mathrm{no}), \mathrm{n}=128\end{array}$ & $(\mathrm{n}=3 / \mathrm{n}=14)$ & $(n=5 / n=92)$ & $(\mathrm{n}=2 / \mathrm{n}=8)$ & $0(n=5)$ & $0.037 \dagger$ \\
\hline $\begin{array}{l}\text { nine rise }>50 \% \text { at } 4-10 \text { days after CT exam } \\
\text { c RRT initiated, }(\%)(\mathrm{n}=\mathrm{yes} / \mathrm{n}=\mathrm{no}), \mathrm{n}=110\end{array}$ & $\begin{array}{c}36 \\
(n=5 / n=9)\end{array}$ & $\begin{array}{c}5 \\
(\mathrm{n}=4 / \mathrm{n}=75)\end{array}$ & $0(n=9)$ & $0(\mathrm{n}=8)$ & $<0.001+$ \\
\hline $\mathrm{CRP}$ at CT scan $(\mathrm{mg} / \mathrm{l}), \mathrm{n}=126$ & $\begin{array}{l}186(71- \\
292)\end{array}$ & $71(26-163)$ & $\begin{array}{l}186(74- \\
257)\end{array}$ & $\begin{array}{l}96(42- \\
197)\end{array}$ & $\begin{array}{c}0.005,1 \mathrm{vs} \\
2 p<0.01 \\
1 \text { vs } 4 \\
p<0.05\end{array}$ \\
\hline Total contrast dose $(\mathrm{ml}), \mathrm{n}=111$ & $\begin{array}{l}60(50- \\
100) \\
(\mathrm{n}=15)\end{array}$ & $\begin{array}{c}60(60-70) \\
(\mathrm{n}=96)\end{array}$ & n.a. & n.a. & 0.96 \\
\hline Contrast dose $(\mathrm{ml} / \mathrm{kg}), \mathrm{n}=98$ & $\begin{array}{l}0.80(0.69- \\
\quad 1.22)\end{array}$ & $\begin{array}{l}0.76(0.65- \\
0.94)\end{array}$ & n.a. & n.a. & 0.58 \\
\hline \multicolumn{6}{|l|}{ OUTCOME DATA } \\
\hline port at CT exam (\%) $(\mathrm{n}=\mathrm{yes} / \mathrm{n}=\mathrm{no}), \mathrm{n}=144$ & $\begin{array}{c}56 \\
(\mathrm{n}=9 / \mathrm{n}=7)\end{array}$ & $\begin{array}{c}23 \\
(\mathrm{n}=25 / \mathrm{n}=84)\end{array}$ & $\begin{array}{c}18 \\
(\mathrm{n}=2 / \mathrm{n}=9)\end{array}$ & $\begin{array}{c}0 \\
(\mathrm{n}=0 / \mathrm{n}=8)\end{array}$ & $<0.01 \dagger$ \\
\hline 30-day mortality (\%), n=146 & $\begin{array}{c}53 \\
(\mathrm{n}=9 / \mathrm{n}=8) \\
\end{array}$ & $(\mathrm{n}=12 / \mathrm{n}=98)$ & $(\mathrm{n}=2 / \mathrm{n}=9)$ & $(\mathrm{n}=1 / \mathrm{n}=7)$ & $<0.001 \dagger$ \\
\hline
\end{tabular}




\begin{tabular}{|c|c|c|c|}
\hline $\begin{array}{l}\text { (b) Patients without RRT at } \\
\text { CT and eGFR } \geq 30-60 \mathrm{CE}\end{array}$ & $\begin{array}{l}\text { 1. P-creatinine rise }>50 \% \text { at } 4-10 \text { days } \\
\text { after CT exam and/or RRT initiated }(n=5)\end{array}$ & $\begin{array}{l}\text { 2. P-creatinine rise }<50 \% \text { at } 4 \text { - } \\
10 \text { days after } \mathrm{CT} \text { exam }(\mathrm{n}=9)\end{array}$ & $\begin{array}{c}\mathrm{p}- \\
\text { value* }\end{array}$ \\
\hline \multicolumn{4}{|l|}{ DEMOGRAPHICS } \\
\hline Age & $68(65-76)$ & $64(54-70)$ & 0.55 \\
\hline Weight & $72(64-75)$ & $76(79-86)$ & 0.21 \\
\hline \multicolumn{4}{|l|}{ LABORATORY DATA } \\
\hline Pre-Covid P-creatinine & $97(82-106)$ & $97(77-114)$ & 0.95 \\
\hline P-creatinine at $\mathrm{CT}$ & $129(124-130)$ & $143(118-155)$ & 0.49 \\
\hline P-creatinine at $24 \mathrm{~h}$ & $143(126-196)$ & $123(116-139)$ & 0.31 \\
\hline P-creatinine at $48 \mathrm{~h}$ & $163(138-196)$ & $108(103-126)$ & 0.13 \\
\hline P-creatinine at 4-10 days & $207(197-237)$ & $88(68-118)$ & $<0.001$ \\
\hline CRP in $\mathrm{mg} / \mathrm{l}$ & $295(274-331)$ & $136(59-221)$ & 0.06 \\
\hline \multicolumn{4}{|l|}{ OUTCOME } \\
\hline $\begin{array}{l}\text { 30-day mortality }(\%) \\
\text { (n=yes/no) }\end{array}$ & $80(4 / 1)$ & $33(3 / 6)$ & $0.09 \dagger$ \\
\hline
\end{tabular}




\begin{tabular}{|c|c|c|c|}
\hline $\begin{array}{c}\text { (c) Patients with existing RRT at CE CT vs. the } \\
\text { entire non-CE CT group }\end{array}$ & $\begin{array}{l}\text { 1. CE CT and } \\
\text { RRT } \\
(\mathrm{n}=15)\end{array}$ & $\begin{array}{l}\text { 3. Non-CE CT } \\
(\mathrm{n}=24, \text { including } 19 \text { without } \\
\text { and } 5 \text { with RRT) }\end{array}$ & p-value* \\
\hline \multicolumn{4}{|l|}{ DEMOGRAPHICS } \\
\hline Men/women (n) & $13 / 2$ & $18 / 6$ & 0.37 \\
\hline Age (years) & $59(55-64)$ & $62(48-67)$ & 0.65 \\
\hline Weight (kg) & $85(70-100)$ & $76(68-90)$ & 0.16 \\
\hline BMI $\left(\mathrm{kg} / \mathrm{m}^{2}\right)$ & $28(24-32)$ & $25(23-27)$ & 0.08 \\
\hline $\begin{array}{c}\text { Thromboembolic treatment } \\
24 \mathrm{~h} \text { before CT exam (\%) (n=no/yes), } \mathrm{n}=37\end{array}$ & $\begin{array}{c}87 \\
(\mathrm{n}=2 / \mathrm{n}=13)\end{array}$ & $86(n=3 / n=19)$ & 0.98 \\
\hline \multicolumn{4}{|l|}{ CO-MORBIDITIES } \\
\hline $\begin{array}{l}\text { Renal disease } \\
(\%)(n=\text { no/yes })\end{array}$ & $7(1 / 14)$ & $30(7 / 17)$ & 0.08 \\
\hline $\begin{array}{l}\text { Hypertension } \\
\text { (\%) }(\mathrm{n}=\text { no/yes })\end{array}$ & $36(5 / 9)$ & $43(10 / 13)$ & 0.64 \\
\hline $\begin{array}{l}\text { Heart failure } \\
(\%)(\mathrm{n}=\text { no/yes })\end{array}$ & $0(0 / 15)$ & $13(3 / 20)$ & 0.14 \\
\hline $\begin{array}{c}\text { Type } 2 \text { diabetes } \\
(\%)(\mathrm{n}=\text { no/yes })\end{array}$ & $13(2 / 13)$ & $26(6 / 17)$ & 0.35 \\
\hline \multicolumn{4}{|l|}{ LABORATORY DATA } \\
\hline P-creatinine, $n=39$ & $\begin{array}{c}161(130- \\
232)\end{array}$ & $129(80-187)$ & 0.68 \\
\hline P-creatinine $24 \mathrm{~h}$ after CT exam, $\mathrm{n}=34$ & $\begin{array}{l}151(132- \\
219)\end{array}$ & $108(86-151)$ & 0.47 \\
\hline P-creatinine $48 \mathrm{~h}$ after CT exam, $\mathrm{n}=33$ & $\begin{array}{l}127(105- \\
175)\end{array}$ & $117(74-159)$ & 0.69 \\
\hline P-creatinine 4-10 days after CT exam, n=33 & $\begin{array}{l}188(67-358) \\
\quad(n=14)\end{array}$ & $82(62-131)(n=21)$ & 0.12 \\
\hline $\begin{array}{c}\text { P-creatinine rise } 26.5 \mu \mathrm{mol} / \mathrm{L} \text { or }>50 \% 48 \mathrm{~h} \text { after CT } \\
\text { exam }(\%)(\mathrm{n}=\mathrm{yes} / \mathrm{n}=\mathrm{no}), \mathrm{n}=33\end{array}$ & $\begin{array}{c}29 \\
(\mathrm{n}=4 / \mathrm{n}=10)\end{array}$ & $11(\mathrm{n}=2 / 17)$ & $0.18 \dagger$ \\
\hline $\begin{array}{l}\text { P-creatinine rise }>50 \% 4-10 \text { days after CT (\%) } \\
\qquad(\mathrm{n}=\mathrm{yes} / \mathrm{n}=\mathrm{no}), \mathrm{n}=33\end{array}$ & $\begin{array}{c}36 \\
(\mathrm{n}=5 / \mathrm{n}=9)\end{array}$ & $5(\mathrm{n}=1 / 20)$ & $0.017+$ \\
\hline CRP at CT scan (mg/l) & $101(54-190)$ & $127(74-204)$ & 0.70 \\
\hline Total contrast dose $(\mathrm{ml}), \mathrm{n}=14$ & $\begin{array}{l}110(60- \\
129)\end{array}$ & n.a. & \\
\hline Contrast dose $(\mathrm{ml} / \mathrm{kg}), \mathrm{n}=11$ & $\begin{array}{l}1.10(0.69- \\
1.43)\end{array}$ & n.a. & \\
\hline \multicolumn{4}{|l|}{ OUTCOME DATA } \\
\hline ICU support at CT exam $(\%)(\mathrm{n}=\mathrm{yes} / \mathrm{n}=\mathrm{no}), \mathrm{n}=39$ & $\begin{array}{c}100 \\
(\mathrm{n}=15 / \mathrm{n}=0)\end{array}$ & $25(\mathrm{n}=6 / \mathrm{n}=18)$ & $<0.001 \dagger$ \\
\hline 30-day mortality $(\%)(n=y e s / n=n o), n=39$ & $\begin{array}{l}40 \\
(n=6 / n=9)\end{array}$ & $21(\mathrm{n}=5 / \mathrm{n}=19)$ & $0.20 \dagger$ \\
\hline
\end{tabular}

Values are presented as the median (interquartile range), the number (n), or in percent, as indicated. Statistics are based on: *analysis of variance (ANOVA) with post-hoc Fisher's test or t-test, or ${ }^{\dagger}$ Pearson chi square test. BMI: body mass index; CE: contrast enhancement; CRP: C-reactive protein; CT: computed tomography; eGFR: estimated glomerular filtration rate $\left(\mathrm{ml} / \mathrm{min} \times 1.73 \mathrm{~m}^{2}\right)$; ICU: intensive care unit; n.a.: not applicable; non-CE: CT without CE; P-creatinine: plasma creatinine in $\mu \mathrm{mol} / \mathrm{L}$; RRT: renal replacement therapy

Table 2. Linear regression analysis of variables associated with a $>25 \%$ rise in P-creatinine at $48 \mathrm{~h}$ or $4-10$ days after CT 


\begin{tabular}{|c|c|c|c|c|c|c|}
\hline Variable & $\begin{array}{l}\text { Numbers at } \\
48 \mathrm{~h} / \mathrm{N} \text { at } \\
4-10 \text { days } \\
\text { after CT }\end{array}$ & $\begin{array}{l}\text { Above or } \\
\text { below } \\
\text { median } \\
\text { value }\end{array}$ & $\begin{array}{c}\text { P-creatinine rise } 26.5 \\
\mu \text { mol/L or > } 50 \% \text { at } \\
48 \mathrm{~h} \text { after CT, OR } \\
(95 \% \mathrm{CI})\end{array}$ & p-value & 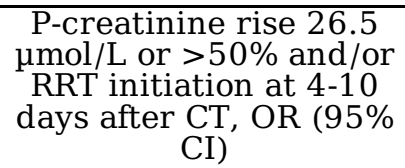 & p-value \\
\hline $\begin{array}{c}\text { P-creatinine } \\
(\mu \mathrm{mol} / \mathrm{L}) \text { at CT }\end{array}$ & $114 / 93$ & $>67$ & $1.7(0.4-6.7)$ & 0.46 & $2.4(0.6-11)$ & 0.22 \\
\hline $\begin{array}{c}\mathrm{eGFR} \geq 30- \\
60 \text { and } \mathrm{CE} \text { at } \mathrm{CT}\end{array}$ & $114 / 93$ & & $5.7(1.3-24)$ & 0.018 & $10.4(2.3-47)$ & 0.002 \\
\hline Dose/weight & $89 / 70$ & $>0.78$ & $0.68(0.14-3.3)$ & 0.63 & $0.9(0.2-3.9)$ & 0.86 \\
\hline Male sex & $114 / 93$ & & $1.2(0.2-6)$ & 0.86 & $3.0 \quad(0.3-26)$ & 0.25 \\
\hline Age (years) & $114 / 102$ & $>59$ & $2.2(0.5-9.4)$ & 0.27 & $4.7(0.9-24)$ & 0.042 \\
\hline $\begin{array}{c}\text { Thromboembolic } \\
\text { treatment }\end{array}$ & $114 / 93$ & & $0.59(0.1-2.6)$ & 0.49 & $0.95(0.2-5)$ & 0.96 \\
\hline ICU care & $113 / 92$ & & $2.0(0.5-8)$ & 0.34 & $5.7(1.2-27)$ & 0.023 \\
\hline 30-day mortality & $114 / 93$ & & $12(2.7-54)$ & $<0.001$ & $16(3-79)$ & $<0.001$ \\
\hline RRT at CT & $128 / 106$ & & $4.7(1.2-18)$ & 0.037 & $5.2(1.4-19)$ & 0.017 \\
\hline
\end{tabular}

$\mathrm{CE}=$ contrast enhancement; $\mathrm{CI}$ : confidence interval; $\mathrm{CT}=$ computed tomography; eGFR: estimated glomerular filtration rate $\left(\mathrm{ml} / \mathrm{min} \times 1.73 \mathrm{~m}^{2}\right) ; \mathrm{h}=$ hours; ICU = intensive care unit; OR: odds ratio; P-creatinine=plasma creatinine; RRT = renal replacement therapy

\section{Figures}

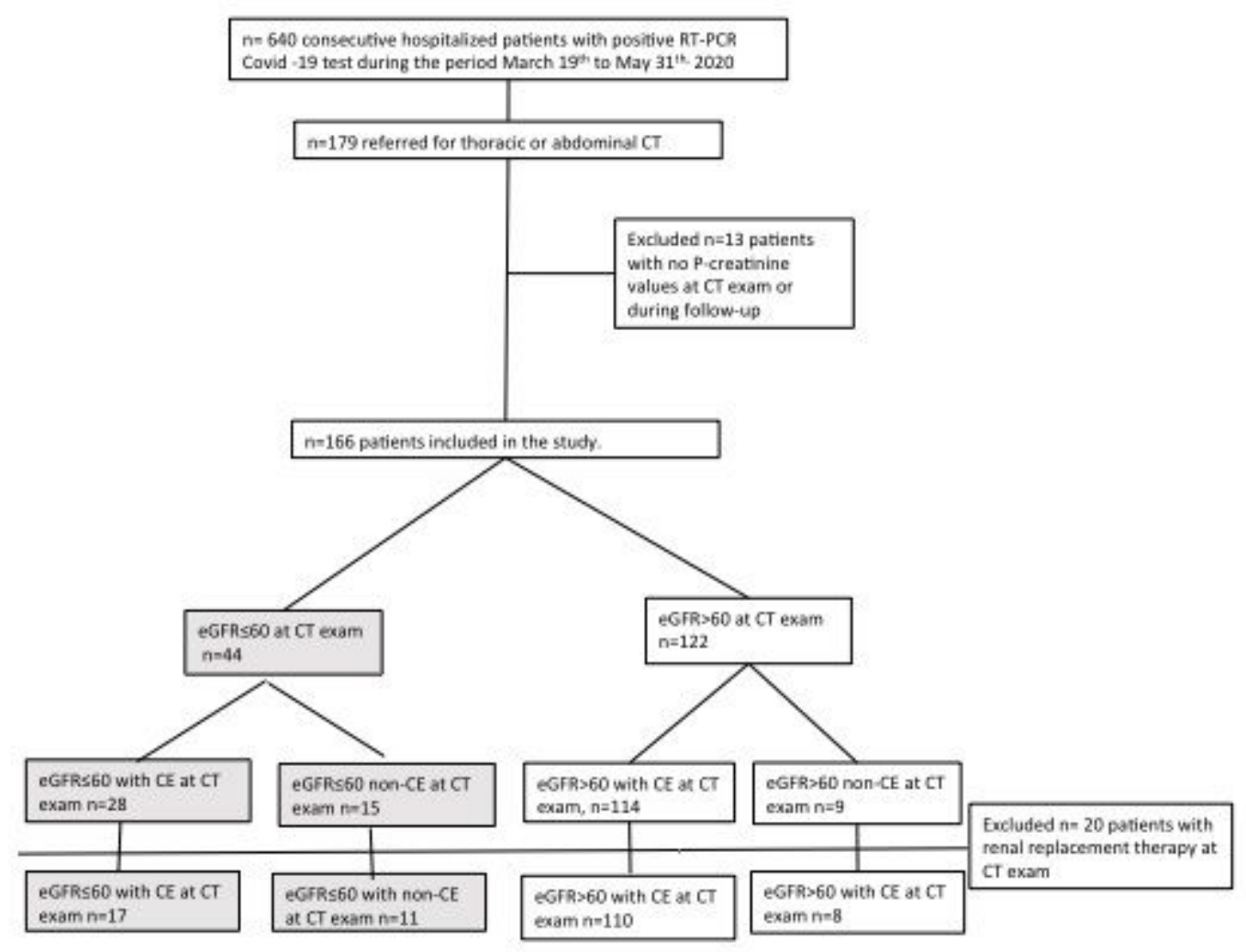

Figure 1 
Flowchart shows the patient selection process. CE: contrast enhancement; CT: computed tomography; eGFR: estimated glomerular filtration rate

2A

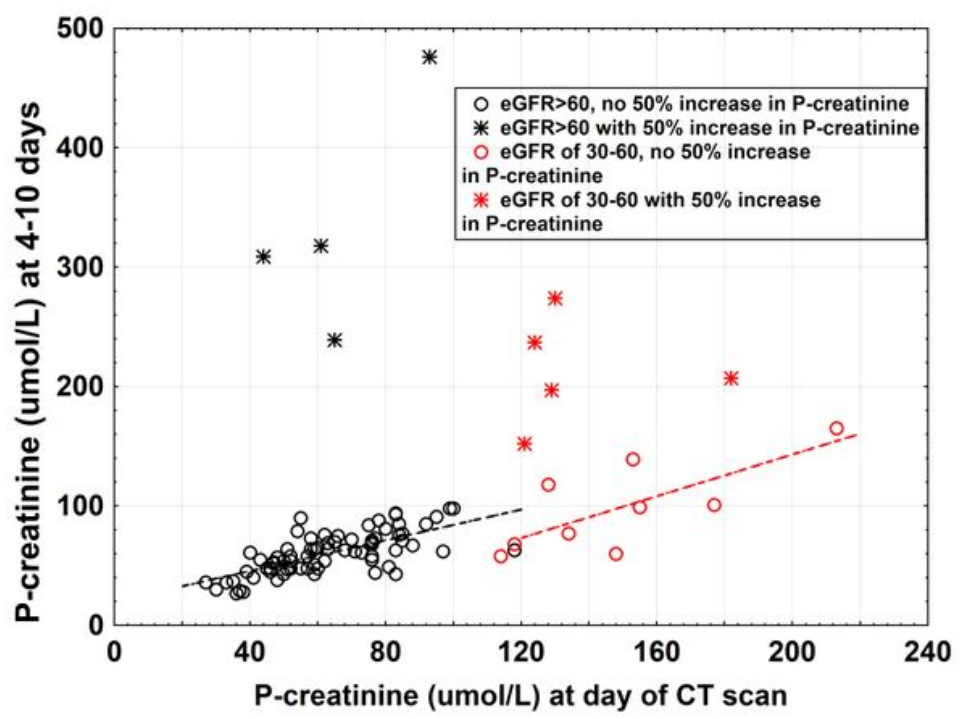

2B

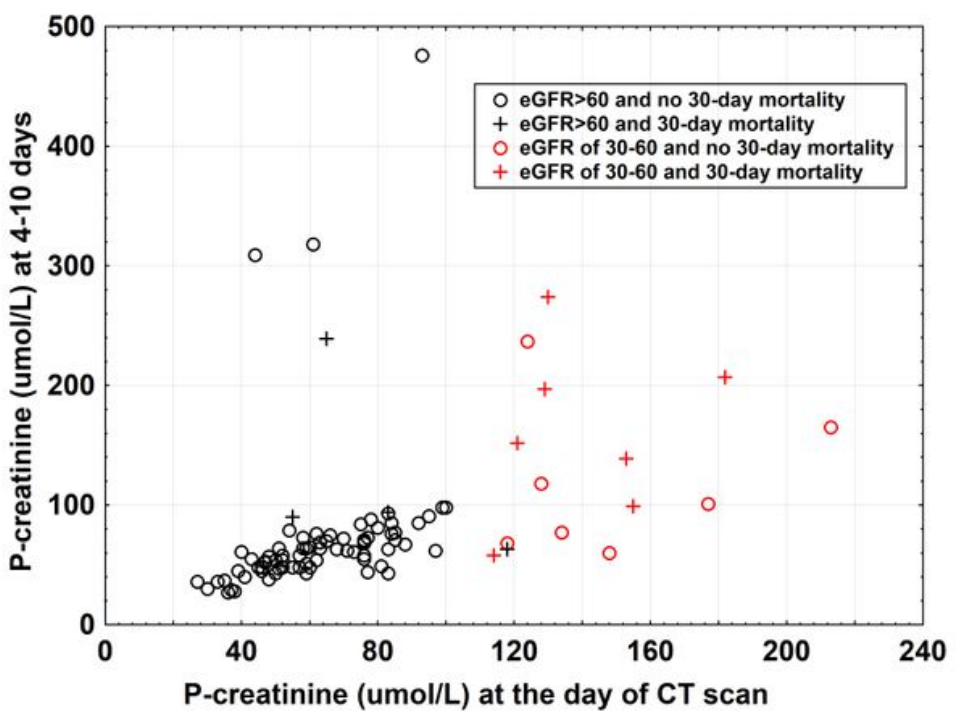

Figure 2

Outcomes, based on eGFR, in patients hospitalized with Covid-19 that underwent CE CT. P-creatinine values $(\mu \mathrm{mol} / \mathrm{L})$ at the time of $\mathrm{CT}$ are plotted relative to P-creatinine values at 4-10 days after $\mathrm{CT}$. Patients with renal replacement therapy (RRT) at the time of CT were excluded. (a) eGFR and a CE-induced rise in P-creatinine. Black unfilled circles or stars represent patients with an eGFR>60 ml/min $\times 1.73 \mathrm{~m} 2(\mathrm{n}=79)$. Black stars indicate patients with a $>50 \%$ rise in P-creatinine at 4-10 days $(n=4)$. Black unfilled circles represent patients without a $>50 \%$ rise in P-creatinine or RRT initiation $(n=75)$. The dashed black line shows the correlation between P-creatinine at CT and P-creatinine at 4-10 days; $(r=0.71, p<0.001)$. Red unfilled circles or stars represent patients with an eGFRof 30-60 ml/min $\times 1.73 \mathrm{~m} 2(\mathrm{n}=14)$. Red stars indicate patients with a $>50 \%$ rise in P-creatinine or an RRT initiation $(n=5)$. Red unfilled circles represent patients without a $>50 \%$ rise in P-creatinine or an RRT initiation $(n=9)$. The dashed red line shows the correlation between P-creatinine at CT and P-creatinine at 4-10 days $(r=0.74, p=0.024)$. (b) eGFR and 30day mortality. Black unfilled circles and crosses represent patients with an eGFR>60 ml/min $\times 1.73 \mathrm{~m} 2$. 
Black unfilled circles represent patients that did not die within 30 days after CT. Black crosses represent patients that died within 30 days after the $C T$. Red unfilled circles and crosses represent patients with an eGFR of $30-60 \mathrm{ml} / \mathrm{min} \times 1.73 \mathrm{~m} 2$. Red unfilled circles represent patients that did not die within 30 days of the $\mathrm{CT}$. Red crosses represent patients that died within 30 days after the CT. CE: contrast enhancement; CT: computed tomography; eGFR: estimated glomerular filtration rate; P-creatinine: plasma creatinine, RRT: renal replacement therapy. 